\title{
Integration of bioagents with antioxidants to control Powdery Mildew disease in sunflower \\ Heba Yousef*(1)
}

\section{Address:}

Plant Pathology Research Institute, Agricultural Research Center, Giza, Egypt.

*Corresponding author: Heba Yousef, heba.yousef@live.com

Received: 03.04.2021; Accepted: 19.05.2021; Published: 19.05.2021

10.21608/ejar.2021.70835.1099

\section{ABSTRACT}

Powdery mildew disease, caused by Erysiphe cichoracearum, is considered one of the most severe pathogenic threats of sunflower worldwide. This study discusses how to improve the effect of biocontrol agents, as a more economic and ecofriendlier alternative to fungicides, by mixing different bioagents (Trichoderma harzianum and Bacillus subtilis) with different antioxidants (ascorbic acid and salicylic acid), either individually or combined. They were applied to sunflower during two successive seasons to determine their effectiveness in promoting growth and inducing resistance in sunflower against powdery mildew disease under field conditions. Results show that all treatments reduced the severity of powdery mildew disease significantly compared with control. A synergistic effect was noticed when combining $T$. harzianum and salicylic acid led to a significant decrease in powdery mildew disease severity in sunflower in comparison to control. In general, the results suggested that the integration of antioxidants with bioagents showed a better response to control powdery mildew disease than single treatments. Applied treatments in the field significantly increased all of the studied growth parameters, plant length, fresh and dry weight. All treatments showed a remarkable increase in physiological aspects (enzymes activity and total phenol content).

Keywords: Sunflower, powdery mildew, antioxidants, bioagents, induced resistance.

\section{INTRODUCTION}

Sunflower (Helianthus annuus L.) ranks third among several vital oilseed crops. Belonging to Asteraceae, sunflower is considered a great edible oil, because of poly-unsaturated fatty acid content. Several people in Egypt and worldwide depend on sunflower for dietary purposes. Sunflower is a short-term oilseed crop that is often ready to be harvested in 90 120 days. Its seed oil is a high-grade oil rich in vitamins A, E, D, and K and is often used for culinary and medicinal purposes (Joksimovic et al., 2006).

Sunflower is susceptible to many diseases mainly caused by fungi. Among these diseases, powdery mildew caused by Golovinomyces cichoracearum (DC.), (formerly known as Erysiphe cichoracearum), is considered one of the most destructive diseases that could lead to serious and quality yield reductions (Madhusudhan et al., 2017). Powdery mildew severity and its progress rely mainly on favorable conditions like moderate temperatures and high humidity (Sujatha et al., 2018). Its symptoms are very distinctive. White powdery spots, that get bigger as the disease progresses, appear on lower leaves. Several asexual spores are formed, and the mildew can spread to the rest of the plant (Kulkarni et al., 2015).

Using microorganisms to biologically control plant pathogens was proven to be an eco-friendlier alternate method to the commonly used traditional methods of chemical treatments. The use of cultural practices, chemical fungicide, and hybrids resistant to powdery mildew are the main strategies for biologically managing powdery mildew disease of sunflower (Ons et al., 2020). However, these strategies have their drawbacks since fungicide resistance breakdowns have resulted from the arbitrary use of fungicide. Moreover, environmental concerns regarding the negative effects of overusing chemical fungicides have made alternative plant protection methods more favorable (Maroni et al., 2006). The use of induced systemic resistance is the main emerging strategy that addresses this environmental sustainability issue. Besides constitutive barriers, plants have inherent inducible defense mechanisms that enable them to defend themselves against pathogens, such as enhancing their resistance when treated with certain compounds or microorganisms (Oostendorp et al., 2001).

Plant growth-promoting rhizobacteria (PGPR) applications can control plant pathogens (O'Brien, 2017). This good PGPR output affects plants both directly and indirectly; impacting plant promotion directly via developing metabolites which increase plant growth while impacting growth indirectly by removing pathogens through the production of secondary metabolites. (Prasannath, 2017).

Hence, biocontrol strategies tend to provide a plant protection solution that is environmentally friendly, ecologically viable, and has great potential to promote sustainable agriculture. They assist useful microorganisms in the soil as well. Microorganisms in the genera Bacillus, Pseudomonas, Streptomyces, and fungi which belong to the genera Coniothyrium and Trichoderma are the common biocontrol agents used in the disease control of fungal pathogens (Mmbaga et al., 2016).

Trichoderma spp. are the most heavily commercialized and efficient inoculants used to control fungal pathogens (Omomowo et al., 2018). They are a type of soil fungi that are saprophytic, free-living, filamentous, often colonizing plants roots. Some Trichoderma spp., for example, T. harzianum and T. virens are utilized and promoted as biocontrol agents 
against many fungi causing plant pathogens, instead of the chemical pesticides already being used. By triggering multiple defense mechanisms, Trichoderma species show both resistance induction in plants and direct mycoparasitism of phytopathogenic fungi (Shoresh et al., 2010). Enzyme synthesis and secretion, secondary metabolites, and antifungal compounds play a crucial part in all these processes. It was noted by Sawant et al., (2017) that Trichoderma isolates, used as seed treatment, induced resistance to powdery mildew disease, and dramatically improved plant growth.

It has been documented that many strains, which belong to the genus Bacillus, especially $B$. subtilis, are efficient in biologically controlling multiple plant pathogens (Mahmoud et al., 2021). Producing antibiotics by these bacteria is critical for disease inhibition (Osman et al., 2017). Bacteria that are gram-positive, in particular strains of $B$. Subtilis, produce various antibacterial and antifungal antibiotics and fengycin family lipopeptides, which exhibit significant antifungal activities and growth suppression abilities of several plant pathogens (Kim et al., 2010). Recently, the B. subtilis strain was found to be efficient against powdery mildew disease under controlled and field conditions (Hashem et al., 2019). Activating plants natural defense mechanisms is one of the main modern plant protection systems. Systemic acquired resistance (SAR) could be induced in various plants by utilizing chemical inducers. Plant resistance inducers are becoming one of the most important alternative methods for controlling plant diseases, because they are safe and rapidly biodegradable (Ragab et al., 2009; Radhakrishan et al., 2017).

Antioxidants have been effectively utilized in systemic resistance induction of different plants against several plant pathogens (El-Gamal et al., 2007; Dutta, et al., 2016). Their effectiveness has been attributed to triggering several morphological and/or physiological changes in the host's defense-related compounds, which in turn increase the systemic resistance (Göre, 2009). Application of ascorbic acid significantly reduced early blight disease incidence of potato (El-Gamal et al., 2007), and had a good effect on reducing the powdery mildew disease severity in cucumber and pepper plants (Abd El-Kader et al., 2012).

Salicylic acid is critical in inducing resistance of plants to pathogens as well. According to Vallad and Goodman (2004), exogenous application of Salicylic acid has been proven to induce resistance to diseases caused by both bacteria and fungi in plants. After a pathogen attack, salicylic acid is vital for signalling the initiation of plant defense responses. The mode of action of salicylic acid can enhance defense mechanisms in the plant tissue (Canet et al., 2010). Moreover, in several crops, salicylic acid can cause pathogenesis-related proteins (PRP) to accumulate, which results in a decrease in disease incidence. Application of salicylic acid and ascorbic acid stimulates the production of tomatin (phytoalexin) in leaves and stems of plants which are toxic to pathogens (Awadella, 2008).

Considering the importance of sunflower plants and the various prospects of their use, coupled with the fact that powdery mildew disease is one of the most destructive pathogens hindering optimum yield and quality, it is, therefore, necessary to investigate the pathogenic effect of this disease on sunflower plants regarding some growth and yield parameters. Therefore, the objective of the present study is to evaluate the effectiveness of different biological control agents and/or resistance inducing chemicals (antioxidants) instead of fungicides as safer alternative control methods against powdery mildew disease in relation to their ability to induce systemic resistance mechanisms in sunflower plants.

\section{MATERIAL AND METHODS}

\section{Laboratory Experiments:}

\section{Propagation of bioagent:}

Trichoderma harzianum isolate was grown on liquid gliotoxin fermentation medium (GFM) developed by Brian and Hemming (1945) for 10 days under complete darkness condition at 25으 to stimulate toxin production. Bacillus subtilis isolate was grown in liquid nutrient glucose medium (NGM) developed by Dowson (1957) for 2 days at 25ㄷ. The two bioagents were prepared as a suspension at a concentration of $30 \times 10^{6} \mathrm{CFU} / \mathrm{ml}$ ( $T$. harzianum) and $20 \times 10^{7} \mathrm{CFU} / \mathrm{ml}$ (B. subtilis). To increase adhesive efficiency and enhance bioagent distribution on the surface of treated seeds, suspensions were mixed with $5 \%$ Arabic gum and $0.5 \%$ potassium soap. Both isolates provided by the central lab of organic agriculture, Agricultural Research Center.

\section{Preparation of antioxidants:}

Two organic acids including ascorbic and salicylic acids (antioxidants) were formulated singly and/or combined. The solution of each organic acid was prepared by dissolving $2 \mathrm{~g} / \mathrm{L}$ water. Seeds of sunflowers cv. 162 were separately dipped in each of these solutions for 30 minutes.

\section{Preparation of a mixture of bioagents:}

To increase the efficacy of the different single bioagents on disease control, combinations of the two used bioagents were prepared. Each mixture was prepared by mixing the two bioagents at the rate of 1:1. The Trichoderma and Bacillus isolates used in this research were not antagonistic to each other, according to in vitro studies.

Preparation of a mixture of bioagents with antioxidants:

The two bioagents were mixed separately either with ascorbic acid or salicylic acid at the rate $1: 1(\mathrm{v}: \mathrm{v})$ to compare the effect of these mixtures with the effect of either single bioagent or single antioxidant and to determine their synergistic effect. 


\section{Field Experiment:}

Effect of two antioxidants and two bioagents on sunflower plants against powdery mildew disease under field conditions:

To study the effects of two antioxidants (ascorbic acid and salicylic acid) along with the two bioagents (T. harzianum and $B$. subtilis) singly and/or mixed on controlling powdery mildew disease infecting sunflower seeds and the resultant effects on plant growth parameters of sunflower, a field experiment was carried out in Agricultural Research Center, Giza governorate for two successive seasons (2018/2019). The experiment was carried out in a randomized complete block design with five replicates per treatment. Each plot consisted of three rows, $30 \mathrm{~cm}$ wide and $3 \mathrm{~m}$ long. Sunflower seeds cv. 162 were dipped in treatments for 30 minutes and kept in cheesecloths for 3 days before sowing. Treated Sunflowers seeds were transplanted in infested plots at the rate of 5 transplants/ plot, with five replicates each. Untreated sunflower seeds cv.162 were used as control. All agricultural practices were performed based on Egypt's Ministry of Agriculture's recommendations.

\section{Experimental design:}

Sixty plots were planted with (2-3 seeds/hill) of sunflower. The antioxidants solutions were prepared at a level of $2000 \mathrm{ppm}$. Suspension of bioagents was prepared at a level of $0.1 \mathrm{~L} / 10 \mathrm{~L}$ distilled water each. The grown plants (2-weeks-old) were foliar sprayed by treatments 3 times, with 14 days interval. Five plots were treated with tap water to serve as a control. The other five plots were treated with Topas-100 fungicide (Penconazole) at a dose ( $2.5 \mathrm{ml} / 10 \mathrm{~L})$. After 60 days from planting fresh shoot and root weight, dry shoot weight, and shoot and root length data were recorded.

Treatments for each plot were as follows:

1. Salicylic acid

2. Ascorbic acid

3. Mixing salicylic acid with ascorbic acid

4. B. subtilis

5. T. harzianum

6. Mixing $B$. subtilis with $T$. harzianum

7. Mixing $B$. subtilis with salicylic acid

8. Mixing $B$. subtilis with ascorbic acid

9. Mixing T. harzianum with ascorbic acid

10. Mixing $T$. harzianum with salicylic acid

11. fungicide

12. Control

\section{Disease assessment:}

Disease severity of powdery mildew was recorded periodically at 20 days interval after the disease appearance. Leaves from each treatment were chosen as randomized samples to determine disease severity and were monitored using (0-5) scale and recorded according to the method described by Wheeler (1969) as follows:

$0=$ no infection (leaves are completely healthy), $1=0.1-3 \%$ leaf area covered by mildew, $2=$ more than 3-10 \% leaf area covered by mildew, $3=$ more than $10-25 \%$ leaf area covered by mildew, $4=$ more than $25-50 \%$ of leaf area covered by mildew, $5=$ more than $75 \%$ of the plant growth covered by the infection.

Disease severity index of powdery mildew was estimated using the following formula:

$$
\text { D.S.I. }=\frac{\sum(n x v)}{Z N} \times 100
$$

Where:

D.S.I. = Disease severity index, $\mathrm{n}=$ Number of leaves in each category, $\mathrm{v}=$ Numerical value of each category, $\mathrm{Z}=$ Numerical value of highest category and $\mathrm{N}=$ Total number of leaves in the sample.

Treatment efficiency (\%) in reducing the disease infection was calculated as follows: $\%$ Treatment efficiency $=\{($ Control-treatment $) /$ Control $\} \times 100$

Chemical analysis:

Preparation of enzyme extract:

Enzyme extracts were prepared following the Maxwell and Bateman method (1967). Each treatment's dry tissues (0.5 g) were ground in a mortar in $3 \mathrm{ml}$ sodium phosphate buffer at $\mathrm{pH} 6.8$ and centrifuged for 20 minutes at $6{ }^{\circ} \mathrm{C}$. For enzyme assays, the resulting supernatant fluids were processed.

\section{Peroxidase activity (PO):}

The activity of peroxidase was measured calorimetrically based on the oxidation of pyrogallol to pyrogalline and using $\mathrm{H}_{2} \mathrm{O}_{2}$ at $430 \mathrm{~nm}$ (Thimmaiah, 1999). The reaction mixture contained $0.5 \mathrm{ml}$ of $0.1 \mathrm{M}$ sodium phosphate buffer solution at $\mathrm{pH}=7.0$, $0.3 \mathrm{ml}$ enzyme extract, $0.3 \mathrm{ml}$ of $0.05 \mathrm{M}$ pyrogallol and $0.1 \mathrm{ml}$ of $1.0 \% \mathrm{H}_{2} \mathrm{O}_{2}$, then completed with buffer up to $3.0 \mathrm{ml}$. Optical density was measured in all the test tubes. The increase in the absorbance at $430 \mathrm{~nm}$ was recorded against blank with phosphate buffer instead of enzyme extract. One unit of enzyme activity was expressed as changes in absorbance per $\mathrm{min}$ at $425 \mathrm{~nm}$ at $25^{\circ} \mathrm{C}$ under standard assay conditions. 


\section{Polyphenol oxidase activity (PPO):}

The activity of polyphenoloxidase was calculated using the Maxwell and Bateman colorimetric method (1967). The reaction mixture contained $1.0 \mathrm{ml}$ sample extract, $1.0 \mathrm{ml}$ of $0.2 \mathrm{M}$ sodium phosphate buffer at $\mathrm{pH}=7.0$ and $1.0 \mathrm{ml}$ of $10-3 \mathrm{M}$ catechol and then complete the final volume to $6.0 \mathrm{ml}$ with buffer. The mixture was incubated for $30 \mathrm{~min}$ at $30^{\circ} \mathrm{C}$. The amount of the enzyme that produces an increase of 0.001 absorbance units/ mins at $25^{\circ} \mathrm{C}$ is known as one unit of enzyme activity.

\section{Catalase activity:}

The activity of catalase enzyme was determined as described by Aebi (1974). Enzyme extract $0.1 \mathrm{ml}$ was added to $2.9 \mathrm{ml}$ of a reaction mixture containing $0.3 \mathrm{M} \mathrm{H}_{2} \mathrm{O}_{2} 5 \%$ and $0.5 \mathrm{M}$ sodium phosphate buffer ( $\mathrm{pH}$ 7.6). The activity of catalase was measured by monitoring the reduction in the absorbance at $240 \mathrm{~nm}$ as a result of $\mathrm{H}_{2} \mathrm{O}_{2}$ consumption. Catalase activity was expressed as unit's $\mathrm{min}^{-1} \mathrm{mg}^{-1}$ protein. One unit of enzyme activity was defined as the decomposition of $1 \mu \mathrm{mol}$ of $\mathrm{H}_{2} \mathrm{O}_{2}$ per $\min$.

\section{Determination of phenolic contents:}

Free, conjugated, and total phenols were determined by mixing one $\mathrm{ml}$ of the sample extract with $0.25 \mathrm{ml} \mathrm{HCl}$ and boiled in a water bath for 10 minutes then left to cool. One $\mathrm{ml}$ of the folin reagent and $6 \mathrm{ml} \mathrm{Na}_{2} \mathrm{CO}_{3}$, were added. The mixture was completed to the final volume $(10 \mathrm{ml})$ using distilled water. Color optical density of the reacted mixture was measured on an absorbance spectrophotometer at $520 \mathrm{~nm}$ (Zieslin and Ben-Zaken, 1993). Phenol content was determined as $\mathrm{mg} / \mathrm{g}$ fresh weight/min.

\section{Data Analysis:}

These experiments were repeated three times to confirm the results. The following data analysis represents the mean of these results. As outlined by Gomez and Gomez, (1984), data attained were subjected to statistical analysis of variance. Duncan's multiple range test at $p<0.05$ level was used for means separation.

\section{RESULTS}

Effect of two antioxidants and two bioagents on the disease severity of sunflower powdery mildew disease under field conditions during the two growing seasons 2018 and 2019:

Data illustrated in Table (1 \& 2) indicate that disease severity of powdery mildew was significantly decreased by different treatments, which induce resistance in sunflower plants compared to untreated control. Data also indicated that fungicide was recorded the highest percentage efficacy in reducing powdery mildew disease severity compared to other treatments. On the other hand, the combination of $T$. harzianum and Salicylic acid was the best treatment in reducing disease severity and recorded the highest efficacy (82.46 and $78.79 \%$ ) followed by the combination of Ascorbic acid and Salicylic acid (74.80 and $74.24 \%$ ) during the two growing seasons 2018 and 2019, respectively.

Sunflower seed yield production was significantly varied among different treatments during the two seasons, 2018 and 2019. In this respect, the highest total seed yield in the two seasons, except fungicide treatment, was the treatment of $T$. harzianum and Salicylic acid followed by a combination of Ascorbic acid and Salicylic acid.

Table (1): Effect of the two antioxidants, the two bioagents, and a combination of them on the disease severity of sunflower powdery mildew disease under field conditions during the growing season 2018.

\begin{tabular}{|c|c|c|c|c|}
\hline \multirow[b]{2}{*}{ Treatment(s) } & \multicolumn{4}{|c|}{ First season (2018) } \\
\hline & Disease Severity\% & Efficiency (\%) & Seed yield (kg/plot) & Increase (\%) \\
\hline Ascorbic acid & $21.3^{\mathrm{e}}$ & 57.01 & $1.60^{a b c}$ & 25.98 \\
\hline Salicylic acid & $15.2^{\mathrm{h}}$ & 69.35 & $1.96^{\mathrm{ab}}$ & 54.33 \\
\hline Ascorbic acid + Salicylic acid & $12.5^{i}$ & 74.80 & $2.08^{\mathrm{ab}}$ & 63.78 \\
\hline B. subtilis & $33.2^{\mathrm{b}}$ & 33.06 & $1.32^{\mathrm{bc}}$ & 3.94 \\
\hline T. harzianum & $17.3^{g}$ & 65.12 & $1.83^{\mathrm{abc}}$ & 44.09 \\
\hline B. subtilis $+T$. harzianum & $24.1^{\mathrm{d}}$ & 51.11 & $1.57^{\mathrm{abc}}$ & 23.62 \\
\hline B. subtilis + Ascorbic acid & $16.8^{\mathrm{h}}$ & 66.13 & $1.91^{\mathrm{abc}}$ & 50.39 \\
\hline B. subtilis + Salicylic acid & $19.5^{f}$ & 60.69 & $1.75^{\mathrm{abc}}$ & 37.80 \\
\hline T. harzianum +Ascorbic acid & $30.1^{c}$ & 39.31 & $1.39 \mathrm{bc}$ & 9.45 \\
\hline T. harzianum + Salicylic acid & $8.7^{j}$ & 82.46 & $2.15^{\mathrm{ab}}$ & 69.29 \\
\hline Fungicide & $6.2^{\mathrm{k}}$ & 87.50 & $2.38^{\mathrm{a}}$ & 87.4 \\
\hline Control & $49.6^{a}$ & -- & $1.27^{c}$ & -- \\
\hline
\end{tabular}


Table (2): Effect of the two antioxidants, the two bioagents, and a combination of them on the disease severity of sunflower powdery mildew disease under field conditions during the growing season 2019.

\begin{tabular}{|c|c|c|c|c|}
\hline \multirow[b]{2}{*}{ Treatment(s) } & \multicolumn{4}{|c|}{ Second season (2019) } \\
\hline & $\begin{array}{c}\text { Disease } \\
\text { Severity\% }\end{array}$ & Efficiency (\%) & $\begin{array}{l}\text { Seed yield } \\
\text { (kg/plot) }\end{array}$ & Increase (\%) \\
\hline Ascorbic acid & $19.7 b^{c}$ & 62.69 & $2.27^{\mathrm{abcd}}$ & 42.77 \\
\hline Salicylic acid & $16.5^{d}$ & 68.75 & $2.65^{\mathrm{abc}}$ & 66.67 \\
\hline Ascorbic acid + Salicylic acid & $13.6^{\mathrm{e}}$ & 74.24 & $2.72^{\mathrm{ab}}$ & 71.07 \\
\hline B. subtilis & $25.7^{a}$ & 51.33 & $1.89^{\mathrm{bcd}}$ & 18.87 \\
\hline T. harzianum & $17.0^{d}$ & 67.80 & $2.57^{a b c}$ & 61.64 \\
\hline B. subtilis + T. harzianum & $20.9^{\mathrm{b}}$ & 60.42 & $2.04^{\mathrm{abcd}}$ & 28.3 \\
\hline B. subtilis + Ascorbic acid & $18.3^{\mathrm{cd}}$ & 65.34 & $2.61^{\mathrm{abc}}$ & 64.15 \\
\hline B. subtilis + Salicylic acid & $20.6^{b}$ & 61.33 & $2.6^{\mathrm{abc}}$ & 63.52 \\
\hline T. harzianum +Ascorbic acid & $24.8^{a}$ & 53.30 & $1.82^{\mathrm{cd}}$ & 14.46 \\
\hline T. harzianum + Salicylic acid & $11.2^{\mathrm{b}}$ & 78.79 & $2.79^{\mathrm{ab}}$ & 75.47 \\
\hline Fungicide & $8.9^{f}$ & 83.15 & $2.81^{a}$ & 76.73 \\
\hline Control & $52.8^{g}$ & -- & $1.59^{d}$ & -- \\
\hline \multicolumn{5}{|c|}{$\begin{array}{l}\text { Means in each column followed by similar letters are not significantly different }(P \leq 0.05) \text { according to Duncan`s multiple } \\
\text { range test. } \\
\text { *Each value represents the mean of five replicates. }\end{array}$} \\
\hline
\end{tabular}

Effect of two antioxidants and two bioagents on vegetative characteristics of sunflower under field conditions during the two growing seasons 2018 and 2019:

Data in Tables ( 3 \& 4) illustrate the vegetative characteristics of the two antioxidants (Ascorbic acid and Salicylic acid) and the two bioagents (B. subtilis and T. harzianum) on plant growth of sunflower cv. 162. Out of the treatments, $T$. harzianum, as well as $B$. subtilis combined with salicylic acid, showed remarkable improvement in total plant fresh weight and dry shoot weight of infected sunflower. However, the dual treatment of $T$. harzianum and salicylic acid appeared to be most effective in increasing total plant fresh weight (63.5 and 61.3\%) and shoot dry weight (99.4 and $119.0 \%$ ) compared to control during the two growing seasons 2018 and 2019, respectively. Using B. subtilis alone, the lowest values in fresh and dry shoot weights were noticed. It was obvious that plots receiving fungicides showed a significant $(P \leq 0.05)$ increment in fresh shoot weight $(57.8 \%)$ and shoot dry weight (120.4 and 140\%) compared to control during the two growing seasons 2018 and 2019, respectively.

Table (3): Effect of the two antioxidants, the two bioagents, and a combination of them on vegetative characteristics of sunflower against powdery mildew disease under field conditions during the growing season 2018.

\begin{tabular}{|c|c|c|c|c|c|c|c|c|}
\hline \multicolumn{9}{|c|}{ First season (2018) } \\
\hline \multirow[b]{2}{*}{ Treatment(s) } & \multicolumn{2}{|c|}{ Length $(\mathrm{cm})$} & \multicolumn{2}{|c|}{ Weight (g) } & \multirow{2}{*}{$\begin{array}{l}\text { Total } \\
\text { fresh } \\
\text { weight }\end{array}$} & \multirow{2}{*}{$\begin{array}{c}\text { Increase } \\
\%\end{array}$} & \multirow{2}{*}{$\begin{array}{c}\text { Shoot } \\
\text { dry } \\
\text { weight }\end{array}$} & \multirow{2}{*}{$\begin{array}{c}\text { Increase } \\
\%\end{array}$} \\
\hline & Shoot & Root & Shoot & Root & & & & \\
\hline Ascorbic acid & $70.7^{k}$ & $39.3^{a}$ & $72.8^{\mathrm{e}}$ & $3.48 a$ & $76.28^{f}$ & 28.7 & $10.40^{\mathrm{cd}}$ & 55.7 \\
\hline Salicylic acid & $106.8^{f}$ & $30.2^{\mathrm{d}}$ & $76.5^{d}$ & $2.29 a$ & $78.79^{d}$ & 40.3 & $11.04^{c}$ & 65.3 \\
\hline Ascorbic acid + Salicylic acid & $109.3^{\mathrm{e}}$ & $27.0^{\mathrm{e}}$ & $80.1^{c}$ & $3.36 a$ & $83.46^{c}$ & 48.7 & $11.72^{\mathrm{bc}}$ & 75.4 \\
\hline B. subtilis & $102.6^{\mathrm{g}}$ & $18.8^{\mathrm{h}}$ & $64.9^{f}$ & $3.04 a$ & $67.91^{\mathrm{g}}$ & 21.0 & $8.40^{\mathrm{de}}$ & 25.7 \\
\hline T. harzianum & $142.8^{\mathrm{a}}$ & $21.6^{g}$ & $84.4^{\mathrm{b}}$ & $3.08 a$ & $87.48^{\mathrm{b}}$ & 55.8 & $10.92^{c}$ & 63.5 \\
\hline B. subtilis + T. harzianum & $125.7^{c}$ & $33.0^{c}$ & $72.6^{\mathrm{e}}$ & $3.44^{a}$ & $76.04^{\mathrm{e}}$ & 35.4 & $9.76^{\mathrm{cd}}$ & 46.1 \\
\hline B. subtilis + Ascorbic acid & $97.3^{\mathrm{i}}$ & $34.5^{\mathrm{bc}}$ & $76.4^{d}$ & $3.28^{a}$ & $79.68^{d}$ & 41.9 & $10.80^{c}$ & 61.7 \\
\hline B. subtilis + Salicylic acid & $118.7^{d}$ & $32.5^{c}$ & $80.7^{c}$ & $3.24^{\mathrm{a}}$ & $83.94^{\mathrm{c}}$ & 49.5 & $10.92^{c}$ & 63.5 \\
\hline T. harzianum +Ascorbic acid & $100.0^{\mathrm{h}}$ & $33.6^{c}$ & $72.8^{\mathrm{e}}$ & $3.20^{\mathrm{a}}$ & $76.00^{\mathrm{e}}$ & 35.4 & $10.88^{c}$ & 35.9 \\
\hline T. harzianum + Salicylic acid & $126.8^{\mathrm{c}}$ & $30.1^{d}$ & $88.7^{a}$ & $3.08^{a}$ & $91.78^{\mathrm{a}}$ & 63.5 & $13.32^{\mathrm{ab}}$ & 99.4 \\
\hline Fungicide & $132.0^{\mathrm{b}}$ & $25.6^{\mathrm{ef}}$ & $84.8^{\mathrm{b}}$ & $3.80^{\mathrm{a}}$ & $88.60^{\mathrm{b}}$ & 57.8 & $14.72^{\mathrm{a}}$ & 120.4 \\
\hline Control & $86.4^{j}$ & $24.0^{f}$ & $52.7^{g}$ & $3.44^{a}$ & $56.14^{\mathrm{h}}$ & 0.0 & $6.68^{e}$ & 0.0 \\
\hline \multicolumn{9}{|c|}{$\begin{array}{l}\text { Means in each column followed by similar letters are not significantly different }(P \leq 0.05) \text { according to Duncan`s multiple } \\
\text { range test. } \\
\text { *Each value represents the mean of five replicates. }\end{array}$} \\
\hline
\end{tabular}


Table (4): Effect of the two antioxidants, the two bioagents, and a combination of them on vegetative characteristics of sunflower against powdery mildew disease under field conditions during the two growing season 2019.

\begin{tabular}{|c|c|c|c|c|c|c|c|c|}
\hline \multicolumn{9}{|c|}{ Second season (2019) } \\
\hline \multirow[b]{2}{*}{ Treatment(s) } & \multicolumn{2}{|c|}{ Length $(\mathrm{cm})$} & \multicolumn{2}{|c|}{ Weight (g) } & \multirow{2}{*}{$\begin{array}{c}\text { Total } \\
\text { fresh } \\
\text { weight }\end{array}$} & \multirow{2}{*}{$\begin{array}{c}\text { Increase } \\
\%\end{array}$} & \multirow{2}{*}{$\begin{array}{l}\text { Shoot } \\
\text { dry } \\
\text { weight }\end{array}$} & \multirow{2}{*}{$\begin{array}{c}\text { Increase } \\
\%\end{array}$} \\
\hline & Shoot & Root & Shoot & Root & & & & \\
\hline Ascorbic acid & $77.4^{b}$ & $31.7^{a}$ & $70.5^{\mathrm{e}}$ & $2.98^{\mathrm{a}}$ & $73.48^{\mathrm{abc}}$ & 45.7 & $8.92^{\text {def }}$ & 53.0 \\
\hline Salicylic acid & $83.2^{\mathrm{b}}$ & $27.3 e^{f}$ & $71.6^{\text {de }}$ & $1.87^{\mathrm{a}}$ & $73.47^{\mathrm{abc}}$ & 45.8 & $10.76^{\mathrm{bcd}}$ & 84.6 \\
\hline Ascorbic acid + Salicylic acid & $96.5^{b}$ & $25.9^{\text {cdef }}$ & $74.2^{c}$ & $2.53^{a}$ & $76.73^{\mathrm{ab}}$ & 34.4 & $11.15^{\mathrm{a}}$ & 91.3 \\
\hline B. subtilis & $81.3^{\mathrm{b}}$ & $22.0^{f}$ & $60.7^{f}$ & $1.89^{a}$ & $62.59^{\text {cd }}$ & 24.4 & $7.62^{g}$ & 41.6 \\
\hline T. harzianum & $100.7^{b}$ & $24.2^{\text {def }}$ & $77.1^{b}$ & $1.95^{\mathrm{a}}$ & $79.05^{a}$ & 56.8 & $9.13^{\text {def }}$ & 69.7 \\
\hline B. subtilis + T. harzianum & $100.8^{\mathrm{b}}$ & $28.6^{\mathrm{abc}}$ & $71.2^{\text {de }}$ & $2.87^{a}$ & $74.07^{a b c}$ & 46.9 & $8.41^{\text {ef }}$ & 56.3 \\
\hline B. subtilis + Ascorbic acid & $80.9^{b}$ & $30.9^{\mathrm{ab}}$ & $72.9^{\mathrm{cd}}$ & $2.45^{a}$ & $75.35^{a b c}$ & 49.5 & $8.79^{\text {def }}$ & 63.4 \\
\hline B. subtilis + Salicylic acid & $98.4^{b}$ & $28.1^{\mathrm{abcd}}$ & $78.2^{\mathrm{ab}}$ & $2.19^{a}$ & $80.39^{a}$ & 59.5 & $9.77^{\text {cde }}$ & 81.6 \\
\hline T. harzianum +Ascorbic acid & $85.8^{\mathrm{b}}$ & $29.8^{\mathrm{abc}}$ & $70.4^{\mathrm{e}}$ & $2.13^{a}$ & $72.53^{\mathrm{abc}}$ & 43.9 & $9.54^{\text {cdef }}$ & 77.3 \\
\hline T. harzianum + Salicylic acid & $114.9^{\mathrm{b}}$ & $26.9^{\text {bcde }}$ & $79.3^{a}$ & $1.99^{a}$ & $81.29 \mathrm{bc}$ & 61.3 & $12.77^{a}$ & 130.7 \\
\hline Fungicide & $117.6^{\mathrm{a}}$ & $23.7^{\text {def }}$ & $77.5^{\mathrm{ab}}$ & $3.15^{\mathrm{a}}$ & $80.65^{a}$ & 60.0 & $12.95^{\mathrm{a}}$ & 140 \\
\hline Control & $74.9^{\mathrm{b}}$ & $21.9^{f}$ & $48.6^{g}$ & $1.18^{\mathrm{a}}$ & $50.41^{d}$ & -- & $5.83 \mathrm{~g}$ & -- \\
\hline \multicolumn{9}{|c|}{$\begin{array}{l}\text { Means in each column followed by similar letters are not significantly different }(P \leq 0.05) \text { according to Duncan`s multiple } \\
\text { range test. } \\
\text { *Each value represents the mean of five replicates. }\end{array}$} \\
\hline
\end{tabular}

Effect of two antioxidants and two bioagents on phenolic contents of sunflower under field conditions during the two growing seasons 2018 and 2019:

Results represented in Tables $(5 \& 6)$ show that phenolic contents including the free, conjugated, and total phenols were noticeably greater in some treated plants than the control during the two growing seasons 2018 and 2019. The highest total phenolic contents were induced by fungicide followed by the combination of $T$. harzianum and salicylic acid treatment which recorded (14.06 and 12.07) in the first season and (1.63 and 12.95) in the second season. Data indicated that phenol contents were affected by the tested bioagents and antioxidants in sunflower during the two growing seasons 2018 and 2019.

Table (5): Effect of the two antioxidants, the two bioagents, and a combination of them on phenolic content of sunflower against powdery mildew disease under field conditions during the growing season 2018.

\begin{tabular}{|c|c|c|c|}
\hline \multicolumn{4}{|c|}{ First season (2018) } \\
\hline \multirow{2}{*}{ Treatment(s) } & \multicolumn{3}{|c|}{ Phenol components (mg/g fresh weight $/ \mathrm{min}$ ) } \\
\hline & Total phenols & Conjugated phenols & Free phenol \\
\hline Ascorbic acid & $4.60^{\mathrm{fg}}$ & $2.05^{\mathrm{fg}}$ & $2.55^{\mathrm{ab}}$ \\
\hline Salicylic acid & $6.75^{\text {de }}$ & $4.9^{\mathrm{de}}$ & $1.85^{\mathrm{ab}}$ \\
\hline Ascorbic acid + Salicylic acid & $8.29^{\mathrm{cd}}$ & $6.32^{\mathrm{cd}}$ & $1.97^{\mathrm{ab}}$ \\
\hline B. subtilis & $5.10^{\mathrm{ef}}$ & $3.42^{\mathrm{efg}}$ & $1.68^{\mathrm{ab}}$ \\
\hline T. harzianum & $8.27^{c d}$ & $6.23^{\mathrm{cd}}$ & $2.04^{\mathrm{ab}}$ \\
\hline B. subtilis $+T$. harzianum & $9.76^{c}$ & $7.45^{c}$ & $2.31^{\mathrm{ab}}$ \\
\hline B. subtilis + Ascorbic acid & $6.92^{\mathrm{de}}$ & $4.6^{\mathrm{de}}$ & $2.32^{\mathrm{ab}}$ \\
\hline B. subtilis + Salicylic acid & $6.88^{\text {de }}$ & $3.96^{\mathrm{ef}}$ & $2.92^{\mathrm{a}}$ \\
\hline T. harzianum +Ascorbic acid & $9.61^{c}$ & $7.55^{c}$ & $2.06^{\mathrm{ab}}$ \\
\hline T. harzianum + Salicylic acid & $12.07^{b}$ & $9.66^{b}$ & $2.41^{\mathrm{ab}}$ \\
\hline Fungicide & $14.06^{\mathrm{ab}}$ & $11.62^{\mathrm{ab}}$ & $2.44^{\mathrm{ab}}$ \\
\hline Control & $3.45^{\mathrm{fg}}$ & $2.31^{\mathrm{fg}}$ & $1.14^{\mathrm{ab}}$ \\
\hline \multicolumn{4}{|c|}{$\begin{array}{l}\text { Means in each column followed by similar letters are not significantly different }(P \leq 0.05) \text { according to Duncan`s multiple } \\
\text { range test. } \\
\text { *Each value represents the mean of five replicates. }\end{array}$} \\
\hline
\end{tabular}


Table (6): Effect of the two antioxidants, the two bioagents, and a combination of them on phenolic content of sunflower against powdery mildew disease under field conditions during the growing season 2019.

\begin{tabular}{|c|c|c|c|}
\hline \multicolumn{4}{|c|}{ Second season (2019) } \\
\hline \multirow{2}{*}{ Treatment(s) } & \multicolumn{3}{|c|}{ Phenol components (mg/g fresh weight/min) } \\
\hline & Total phenols & Conjugated phenols & Free phenol \\
\hline Ascorbic acid & $3.92^{\mathrm{fg}}$ & $2.58^{f}$ & $1.34^{\mathrm{a}}$ \\
\hline Salicylic acid & $4.37^{\mathrm{fg}}$ & $2.40^{f}$ & $1.97^{\mathrm{a}}$ \\
\hline Ascorbic acid + Salicylic acid & $8.01^{\mathrm{cd}}$ & $6.15^{\mathrm{cd}}$ & $1.86^{\mathrm{a}}$ \\
\hline B. subtilis & $5.21^{\mathrm{ef}}$ & $3.56^{\mathrm{ef}}$ & $1.56^{\mathrm{a}}$ \\
\hline T. harzianum & $6.87^{\mathrm{de}}$ & 5.09 de & $1.78^{\mathrm{a}}$ \\
\hline B. subtilis $+T$. harzianum & $10.31^{\mathrm{b}}$ & $8.36^{b}$ & $1.95^{\mathrm{a}}$ \\
\hline B. subtilis + Ascorbic acid & $7.22^{\mathrm{de}}$ & $5.34^{\mathrm{de}}$ & $1.88^{\mathrm{a}}$ \\
\hline B. subtilis + Salicylic acid & $6.95^{\text {de }}$ & $4.88 \mathrm{~d}^{\mathrm{e}}$ & $2.07^{\mathrm{a}}$ \\
\hline T. harzianum +Ascorbic acid & $9.85^{b c}$ & $8.03^{b c}$ & $1.82^{\mathrm{a}}$ \\
\hline T. harzianum + Salicylic acid & $11.63^{\mathrm{ab}}$ & $9.48^{\mathrm{ab}}$ & $2.15^{a}$ \\
\hline Fungicide & $12.95^{\mathrm{a}}$ & $10.66^{a}$ & $2.29^{a}$ \\
\hline Control & $2.79 \mathrm{~g}$ & $1.72 \mathrm{fa}^{\mathrm{a}}$ & $1.07^{a}$ \\
\hline \multicolumn{4}{|c|}{$\begin{array}{l}\text { Means in each column followed by similar letters are not significantly different }(P \leq 0.05) \text { according to Duncan`s multiple } \\
\text { range test. } \\
\text { *Each value represents the mean of five replicates. }\end{array}$} \\
\hline
\end{tabular}

Effect of two antioxidants and two bioagents on oxidative enzymes of sunflower under field conditions during the two growing seasons 2018 and 2019:

Concerning the formation of oxidative enzymes in sunflower, the obtained data in Figures (1 \& 2) indicate that the lowest values of oxidative enzyme were detected in control. Generally, the two antioxidants and the two bioagents either individually or combined succeeded to increase enzymes activity, In this respect, the highest activities in all determine enzymes were induced by a mixture of T.harzianum with salicylic acids compared to any treatments rather than fungicide during the two growing seasons 2018 and 2019. Data also recorded that salicylic acid was the most effective than ascorbic acid on three oxidative enzymes. While two antioxidants were mixed in the rate (1:1) were recorded more effect. When bioagents were evaluated regarding oxidative enzyme, $T$. harzianum showed the highest effect than $B$. subtilis on peroxidase (PO), catalase and polyphenoloxidase (PPO) as single treatment while, a mixture of them due to synergistic effect increased oxidative enzyme activities during the two growing seasons 2018 and 2019.

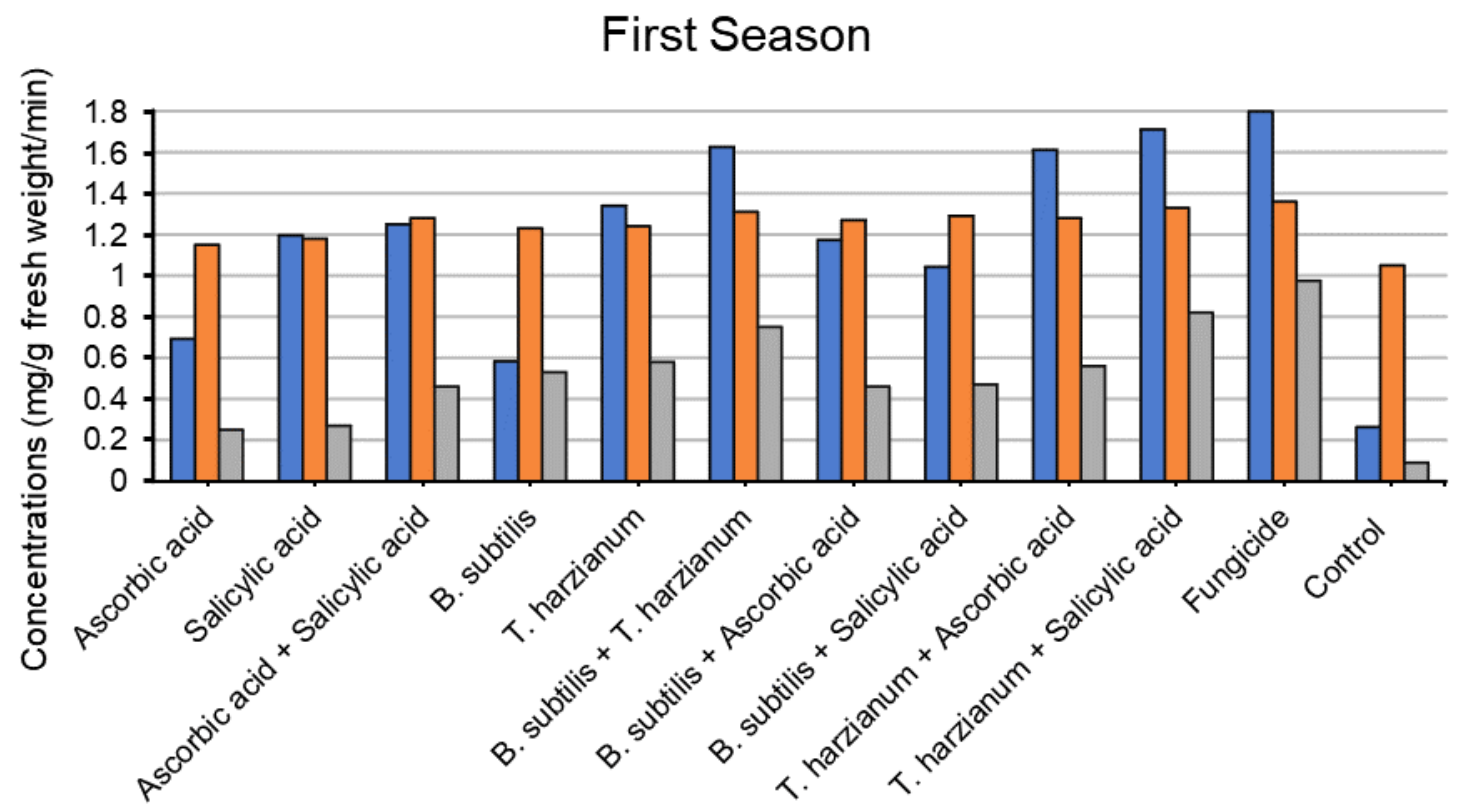

Treatments

口Peroxidase $\square$ Catalase $\quad$ Polyphenol oxidase

Figure (1): Effect of the two antioxidants, the two bioagents, and a combination of them on oxidative enzymes of sunflower against powdery mildew disease under field conditions during the first growing season 2018. 


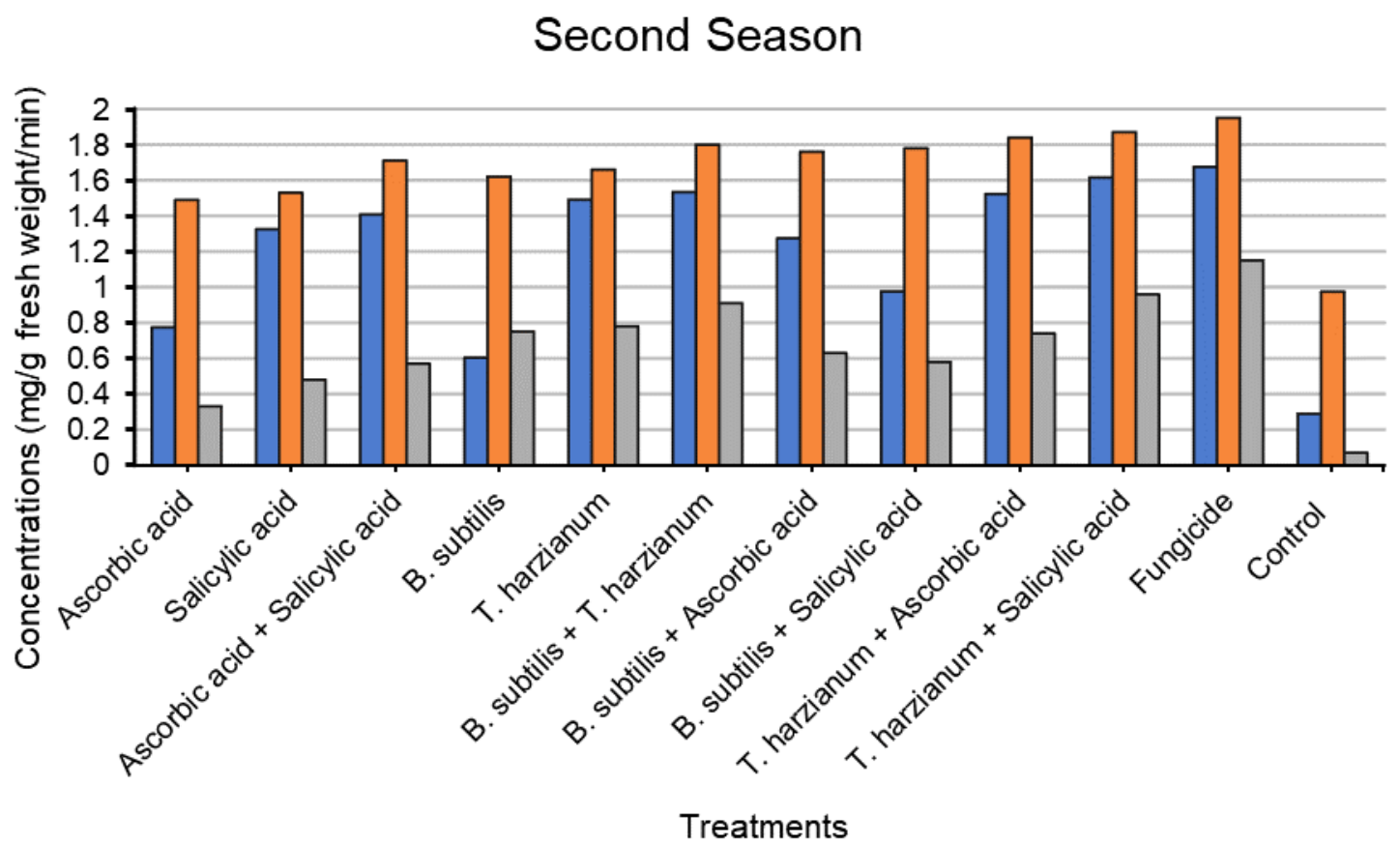

口Peroxidase $\square$ Catalase $\square$ Polyphenol oxidase

Figure (2): Effect of the two antioxidants, the two bioagents, and a combination of them on oxidative enzymes of sunflower against powdery mildew disease under field conditions during the second growing season 2019.

\section{DISCUSSION}

Fungicides have serious polluting effects on humans and the natural environment. Therefore, the current trend in pest management is to rely primarily on using biocides and resistance inducing chemicals instead. In this study, the tested treatments are engaged in the bio-physiological processes of the infected plants. They are important in plants' defense mechanisms against invading pathogens.

Salicylic acid combined with $T$. harzianum has proved to be the most efficient tested treatment in this study during the two growing seasons. Using these treatments can eventually decrease reliance on the use of fungicides in managing plant pathogens of both sensitive and resistant populations, which can, in turn, lead to a reduction in losses of food and eventually the costs of production, which is going to encourage farmers to adopt an integrated approach instead of a fungicide-based one (Ons et al., 2020). The data revealed that the treatment salicylic acid combined with $T$. harzianum caused a significant reduction of sunflower powdery mildew disease with a significant increase in yield and vegetative characteristics such as fresh weight and plant length compared to the control treatment in the two growing seasons, which coincides with the findings of Abdel - Kader et al. (2012). These results also confirmed earlier reports that exogenous salicylic acid induces resistance against pathogens infecting sunflower plants, accumulates in pathogen-infected tissue, and improves the growth of the host plants (Alkahtani et al., 2011).

Our results indicated that antioxidants have the potential in suppressing powdery mildew disease and can be a viable alternative to less eco-friendly synthetic fungicides. They have effectively been used to induce systemic resistance in different plants against several plant diseases (Mmbaga et al., 2016). Plant cells utilize ascorbic acid for the synthesis of mitochondria hydroxyproline proteins which in turn control the development of cyanide-resistant respiration. Ascorbic acid seems to affect plant growth regulation by controlling biosynthesis of proteins containing hydroxyproline. This process is indicated by a number of the biological mechanisms of defense in plants (Kim et al., 2010).

The current study shows the high efficiency of the bioagent $T$. harzianum in reducing disease severity of powdery mildew in sunflower during the two growing seasons. These findings agree with Oyoo-Okoth et al. (2011). Trichoderma is usually a remarkable model for studying biocontrol since it is abundant, easily extracted and cultured, quickly grown on numerous media, impacts different pathogens, functions as a mycoparasite, competes competently for location and food, make antibiotics, possesses an enzyme mechanism that can attack a great variety of plant pathogens (Islam et al., 2008), and acts as an inducer of resistance (Abd El-Moity, 2001).

Bioagents have an effect not only on the outside of the plants, but also on their internal metabolism, resulting in improvements in plant components (Ziedan et al., 2005). Application of $T$. harzianum generally protects crops, especially sunflower, against the powdery mildew disease. It also helps enhance vegetative characteristics of sunflower which has important economic effects such as a decrease in the usage of fertilizer, a reduction in crop duration, an increase in yield, 
offering an eco-friendly approach for managing crop disease, all while being economically viable (Omomowo et al., 2018). This means that it can play a key role in sustainable modern agricultural practices. Trichoderma has a few mechanisms that promote plant growth through improving nutrient availability and intake, leading to effective nutrient uptake, and enhances photosynthesis processes in plants (Harman, 2004). This stimulates plant growth and increases both disease control and the yield of treated plants (Hernandez-Suarez et al., 2011).

In the current study, treatments showed remarkable increase in physiological aspects (oxidative enzymes activities and total phenol content) during the two successive growing seasons, especially $T$. harzianum combined Salicylic acid. This combination had the highest efficiency reducing disease severity of powdery mildew disease. This agrees with Houssien et al. (2010) who stated that a mixture of salicylic acid and Trichoderma allows access to both peroxidase and polyphenoloxidase activities. Oxidative enzymes mechanisms impact infected plants in two different ways; firstly, inhibiting the pathogen by suppressing its life cycle via the direct action of oxidative enzymes, and secondly, restricting the pathogen and enhancing the biocontrol action through inducing mediated phenolic compounds (Mayer, 2006; Saleem et al., 2012). This would also fit the recommendation of the fungicide resistance action committee to lessen the chances of resistance development by reducing the selection pressure on pathogens (Ons et al., 2020). Hafez et al., (2018) found a positive correlation between resistance and oxidative enzymes. Peroxidase also creates hydrogen peroxide that are poisonous to several pathogens, and an increase in its activities, as well as polyphenol oxidase, can prevent disease from spreading via producing phenolic barriers around infection (Elsisi, 2019). Salicylic acid increases the activity of oxidative enzymes (ElLethy et al., 2011), by oxidizing phenolic compounds to quinines, which are essential in the defense mechanism against pathogens, triggering an increase in antimicrobial activity (El-Khallal, 2007). As a result, they can be actively involved in impeding pathogen production by quickening the cells death near the infection site, inhibiting the disease spread through producing a poisonous environment that prevents the development of pathogens in the plant (Khalil and Ashmawy, 2019). All the tested treatments showed an increase in total phenols compared with control which enhanced the plants' ability to inhibit infection and disease progress, these results are in accordance with the results of Daayf et al. (1997).

$T$. harzianum had a greater effect than $B$. subtilis when the tested bioagents were evaluated regarding oxidative enzyme. However, salicylic acid combined with $T$. harzianum showed the highest effect on catalase enzyme, during the two growing seasons. Catalase can participate in defense mechanism of plants pathogens by their action on the cell walls of invading pathogens through removing the harmful oxygen derivatives that are a typical feature in stressful conditions (Foyer et al., 1994). Catalase activity reduces the amount of hydrogen peroxide in diseased tissues that can build up to toxic levels before being converted to water and free oxygen that possesses its activity. Enzyme activities were increased by salicylic acid application (Chen et al., 1993). Another study by Hamza et al. (2017) indicated that when infected with powdery mildew, biochemical alterations occurring at the cellular stage were observed.

Mixing antagonists may result in an antagonistic effect that can subsequently reduce the effectiveness of treatment (Robinson et al., 2009) or cause a synergistic effect and enhance their effectiveness (Yousef et al., 2010; Yobo et al., 2011). However, this study revealed that the efficiency of dual treatment was higher than individual treatments. This synergistic effect can be ascribed to the complementary effects between the various treatments. Several studies reported mixing biocontrol agents with antioxidants to control different pathogens (Abd El-Moity, 2001; Abdel-Kader et al., 2012). This enhancement is caused by harmonic and compatible factors between them.

\section{CONCLUSION}

In conclusion, this study has shown that the combination between antioxidants and bioagent has reduced powdery mildew disease on sunflower. They proved to have the potential to be a more economically viable and eco-friendlier alternative to hazardous chemical fungicides. Moreover, they are efficient protection treatments because they enhance induced resistance in sunflower plants against diseases and can be used in integrated disease management.

Funding: Not applicable.

Conflict of Interest: The authors declare no conflict of interest

\section{REFERENCES}

Abd-El Moity, T. H. (2001, October). A Complete system to produce high quality and quantity strawberries under organic farming conditions. In Proceedings of International symposium Organic Agriculture, Agadir (Vol. 7, No. 10).

Abdel-Kader, M. M., El-Mougy, N. S., Aly, M. D. E., \& Lashin, S. M. (2012). Integration of biological and fungicidal alternatives for controlling foliar diseases of vegetables under greenhouse conditions. International Journal of Agriculture and Forestry, 2(2), 38-48.

Aebi, H. (1974). Catalase. In: Bergmeyer, H.U., Ed., Methods of Enzymatic Analysis, Verlag Chemie/Academic Press Inc., Weinheim/NewYork, 673-680.

Alkahtani, M., Omer, S. A., El-Naggar, M. A., Abdel-Kareem, E. M., \& Mahmoud, M. A. (2011). Pathogenesis-related protein and phytoalexin induction against cucumber powdery mildew by elicitors. International Journal of Plant Pathology, 2(2), 63-71.

Awadalla, O. A. (2008). Induction of systemic acquired resistance in tomato plants against early blight disease. The Egyptian Journal Experimental Biology (Botany), 4, 53-59.

Brian, P. W., \& Hemming, H. G. (1945). Gliotoxin, a fungistatic metabolic product of Trichoderma viride. Annals of Applied Biology, 32(3), 214-220. 
Canet, J. V., Dobón, A., Ibáñez, F., Perales, L., \& Tornero, P. (2010). Resistance and biomass in Arabidopsis: a new model for salicylic acid perception. Plant Biotechnology Journal, 8(2), 126-141.

Daayf, F., Schmitt, A., \& Bélanger, R. R. (1997). Evidence of phytoalexins in cucumber leaves infected with powdery mildew following treatment with leaf extracts of Reynoutria sachalinensis. Plant Physiology. 113,719-727.

Dowson, W. J. (1957). Reviews. Bacterial diseases of plants. Annals of Applied Biology. 45, 237- 9.

Dutta, S., Rieche, F., Eckl, N., Duch, C., \& Kretzschmar, D. (2016). Glial expression of Swiss cheese (SWS), the Drosophila orthologue of neuropathy target esterase (NTE), is required for neuronal ensheathment and function. Disease Models \& Mechanisms, 9(3), 283-294.

El-Gamal, N. G., Abd-El-Kareem, F., Fotouh, Y., \& El-Mougy, N. (2007). Induction of systemic resistance in potato plants against late and early blight diseases using chemical inducers under greenhouse and field conditions. Research Journal of Agricultural Biological Science 3, 73-81.

El-Khallal, S. M. (2007). Induction and modulation of resistance in tomato plants against Fusarium wilt disease by bioagent fungi (arbuscular mycorrhiza) and/or hormonal elicitors (jasmonic acid \& salicylic acid): 1-Changes in growth, some metabolic activities and endogenous hormones related to defence mechanism. Australian Journal of Basic and Applied Science 1(4), 691-705.

El-Lethy, S. R., Ayad, H. S., \& Reda, F. (2011). Effect of riboflavin, ascorbic acid and dry yeast on vegetative growth, essential oil pattern and antioxidant activity of geranium (Pelargonium graveolens L.). American-Eurasian Journal of Agricultural \& Environmental Sciences, 10(5), 781-786.

Elsisi, A. A. (2019). Evaluation of biological control agents for managing squash powdery mildew under greenhouse conditions. Egyptian Journal of Biological Pest Control, 29(1), 1-6.

Foyer, C. H., Descourvieres, P., \& Kunert, K. J. (1994). Protection against oxygen radicals: an important defence mechanism studied in transgenic plants. Plant, Cell \& Environment, 17(5), 507-523.

Gomez, K. A. \& Gomez, A. A. (1984). Statistical Procedures for Agricultural Research. 2nd Ed. New York. USA. John Wiley and Sons.

Göre, M. E. (2009). Epidemic outbreaks of downy mildew caused by Plasmopara halstedii on sunflower in Thrace, part of the Marmara region of Turkey. Plant Pathology, 58(2).

Hafez, Y. M., El-Nagar, A. S., Elzaawely, A. A., Kamel, S., \& Maswada, H. F. (2018). Biological control of Podosphaera xanthii the causal agent of squash powdery mildew disease by upregulation of defense-related enzymes. Egyptian Journal of Biological Pest Control, 28(1), 1-8.

Hamza, A., Mohamed, A., \& Derbalah, A. (2017) Chemical inducers for resistance induction against powdery mildew of cucumber under greenhouse conditions. Acta Phytopathologica et Entomologica Hungarica, 52 (1), 49-60.

Harman, G. E. (2000). Myths and dogmas of biocontrol changes in perceptions derived from research on Trichoderma harzinum T-22. Plant disease, 84(4), 377-393.

Hashem, A., Tabassum, B., \& Fathi Abd_Allah, E. (2019). Bacillus subtilis: A plant-growth promoting rhizobacterium that also impacts biotic stress. Saudi Journal of Biological Sciences, 26(6), 1291-1297.

Hernandez-Suarez, M., Hernandez-Castillo, F. D., Gallegos-Morales, G., Lira-Saldivar, R. H., Rodríguez-Herrera, R., \& Aguilar, C. N. (2011). Biocontrol of soil fungi in tomato with microencapsulates containing Bacillus subtilis. American Journal of Agricultural and Biological Sciences, 6(2), 189-195.

Houssien, A. A., Ahmed, S. M., \& Ismail, A. A. (2010). Activation of tomato plant defense response against Fusarium wilt disease using Trichoderma harzianum and salicylic acid under greenhouse conditions. Research Journal of Agricultural Biological Science, 6(3), 328-338.

Chen, Z., Jiang, J. C., Lin, Z. G., Lee, W. R., Baker, M. E., \& Chang, S. H. (1993). Site-specific mutagenesis of Drosophila alcohol dehydrogenase: evidence for involvement of tyrosine-152 and lysine-156 in catalysis. Biochemistry, 32(13), 33423346.

Islam, M. S., Saha, A. K., Mosaddeque, H. Q. M., Amin, M. R., \& Islam, M. M. (2008). In vitro studies on the reaction of fungi Trichoderma to different herbicides used in tea plantation. International Journal of Sustainable Crop Production 3(5), 27.

Joksimović, J., Atlagić, J., Marinković, R., \& Jovanović, D. (2006). Genetic control of oleic and linoleic acid contents in sunflower/control genético del contenido de aceite oleico y linólico en girasol/contrôle génétique des contenus d'acide oléique et linoléique chez le tournesol. Helia, 29(44), 33-40.

Khalil, M. E., \& Ashmawy, E. M. (2019). Induction of systemic disease resistance in cucumber plants treated by the spray of some biotic and abiotic agents to control downy mildew disease. Egyptian Journal of Agricultural Research, 1(1), 19-37.

Kim, P. I., Ryu, J. W., Kim, Y. H., \& Chi, Y. T. (2010). Production of biosurfactant lipopeptides iturin A, fengycin, and surfactin A from Bacillus subtilis CMB32 for control of Colletotrichum gloeosporioides. Journal of Microbiology and Biotechnology, 20(1), 138-145.

Kulkarni, V., Shankergoud, L., \& Govindappa, M. R. (2015). Identification of sunflower powdery mildew resistance sources under artificial screening. SABRAO Journal of Breeding and Genetics, 47(4), 502-509.

Madhusudhan, P., Narasimhudu, Y., Ashok Kumar, K., Neelima, S. \& Sarma, A. S. R. (2017). Management of Sunflower Powdery Mildew Using Fungicide. International Journal of Current Microbiology and Applied Sciences. 6(7), 12611264.

Mahmoud E. Y., Hussien, Z. N., Ibrahim, M. M., and Yousef, H. (2021). Using of Certain Biotic and Abiotic Inducers on Controlling Peanut Cercospora Leaf Spot. Current Science International 10 (1), 18-28. 
Maroni, M., Fanetti, A. C., \& Metruccio, F. (2006). Risk assessment and management of occupational exposure to pesticides in agriculture. La Medicina del lavoro, 97(2), 430-437.

Maxwell, D. P., \& Bateman, D. F. (1967). Changes in the activities of some oxidases in extracts of Rhizoctonia-infected bean hypocotyls in relation to lesion maturation. Phytopathology, 57(5).

Mayer, A. M. (2006). Polyphenol oxidases in plants and fungi: Going places? Annual Review of Phytochemistry. 67, 23182331.

Mmbaga, M. T., Mrema, F. A., Mackasmiel, L., \& Rotich, E. (2016). Effect of bacteria isolates in powdery mildew control in flowering dogwoods (Cornus florida L.). Crop Protection, 89, 51-57.

O’Brien, P. A. (2017). Biological control of plant diseases. Australasian Plant Pathology, 46(4), 293-304.

Omomowo, I. O., Fadiji, A. E., \& Omomowo, O. I. (2018). Assessment of bio-efficacy of Glomus versiforme and Trichoderma harzianum in inhibiting powdery mildew disease and enhancing the growth of cowpea. Annals of Agricultural Sciences, 63(1), 9-17.

Ons, L., Bylemans, D., Thevissen, K., \& Cammue, B. (2020). Combining Biocontrol Agents with Chemical Fungicides for Integrated Plant Fungal Disease Control. Microorganisms, 8(12), 1930.

Oostendorp, M., Kunz, W., Dietrich, B., \& Staub, T. (2001). Induced disease resistance in plants by chemicals. European Journal of Plant Pathology, 107(1), 19-28.

Osman, E., Hassan, M., Metwaly, H., \& Yousef, H. (2017). Effect of Humic Acid on the Efficacy of some Biocontrol Agents in Controlling Damping-off of Cotton Seedlings Caused by Fusarium oxysporum. Egyptian Journal of Phytopathology, 45(2), 53-66.

Oyoo-Okoth, E., Ngugi, C. C., \& Chepkirui-Boit, V. (2011). Physiological and biochemical responses of Nile tilapia (Oreochromis niloticus) exposed to aqueous extracts of Neem (Azadirachta indica). Journal of Applied Aquaculture, 23(2), 177-186.

Prasannath, K. (2017). Plant defense-related enzymes against pathogens: a review.

Radhakrishnan, R., Hashem, A., \& Abd_Allah, E. F. (2017). Bacillus: A biological tool for crop improvement through biomolecular changes in adverse environments. Frontiers in Physiology, 8, 667.

Ragab, M. M., Saber, M. M., El-Morsy, S. A., \& El-Aziz, A. R. M. A. (2009). Induction of systemic resistance against root rot of basil using some chemical inducers. Egyptian Journal of Phytopathology, 37(1), 59-70.

Robinson, P. H., \& Erasmus, L. J. (2009). Effects of analyzable diet components on responses of lactating dairy cows to Saccharomyces cerevisiae based yeast products: A systematic review of the literature. Animal feed science and technology, 149(3-4), 185-198.

Saleem, A., El-Said, A., Moharram, A., \& Hamed, A. (2012). Cellulose decomposing fungi and cellulase activity as affected by Amistar and Moncut fungicides. African Journal of Microbiology Research. 6, 4457-4470.

Sawant, I. S., Wadkar, P. N., Ghule, S. B., Rajguru, Y. R., Salunkhe, V. P., \& Sawant, S. D. (2017). Enhanced biological control of powdery mildew in vineyards by integrating a strain of Trichoderma afroharzianum with sulphur. Biological Control, 114, 133-143.

Shoresh, M., Harman, G. E., \& Mastouri, F. (2010). Induced systemic resistance and plant responses to fungal biocontrol agents. Annual review of phytopathology, 48, 21-43.

Sujatha, M., Ulaganathan, K., Bhanu, B. D., \& Soni, P. K. (2018). RNA-seq data of control and powdery mildew pathogen (Golovinomyces orontii) treated transcriptomes of Helianthus niveus. Data in Brief, 17, 210-217.

Thimmaiah S. K. (1999). Standard Methods of Biochemical Analysis. New Delhi: Kalyani Pub.

Vallad, G. E., \& Goodman, R. M. (2004). Systemic acquired resistance and induced systemic resistance in conventional agriculture. Crop Science, 44(6), 1920-1934.

Wheeler, B. E. J. (1969). An Introduction to Plant Disease. John Wiley \& Sons Ltd., London.

Yobo, K. S., Laing, M. D., \& Hunter, C. H. (2011). Effects of single and combined inoculations of selected Trichoderma and Bacillus isolates on growth of dry bean and biological control of Rhizoctonia solani damping-off. African Journal of Biotechnology, 10(44), 8746-8756.

Yousef, H., Sahebani, N., Mirabolfathy, M., Faravardeh, L., \& Mahdavi, V. (2011). The effect of salicylic acid and Bacillus subtilis on cucumber root and stem rot, caused by Fusarium oxysporum f. sp. radicis cucumerinum. Iranian Journal of Plant Pathology, 46(4).

Ziedan, E. H., Moataza, M. S., \& Eman, S. F. (2005). Biological control of grapevine root-rot by antagonistic microorganisms. African Journal of Mycology and Biotechnology, 13(3), 19-36.

Zieslin, N., \& Ben-Zaken, R. (1993). Peroxidase activity and presence of phenolic substances in peduncles of rose flowers. Plant physiology and Biochemistry (Paris), 31(3), 333-339.

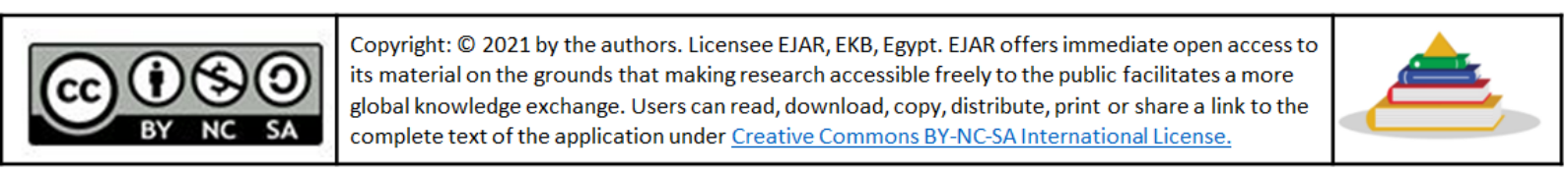


تكامل عوامل المكافحة الحيوية مع مضادات الأكسدة لمقاومة مرض البياض الدقيقي في نبات عباد الشمس

$$
\begin{aligned}
& \text { هبه يوسف } \\
& \text { معهد بحوث أمراض النباتات، مركز البحوث الزراعية، الجيزة، مصر } \\
& \text { * بريد المؤلف المراسل: heba.yousef@live.com }
\end{aligned}
$$

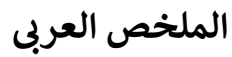

يعد مرض البياض الدقيقي (Erysiphe cichoracearum) من أخطر الأمراض التي تهدد نبات عباد الشمس. تناقش

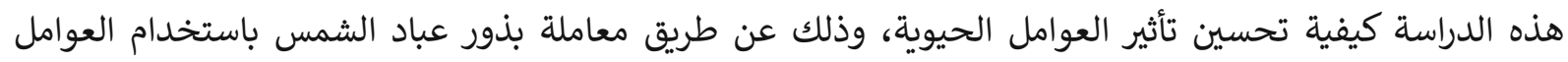

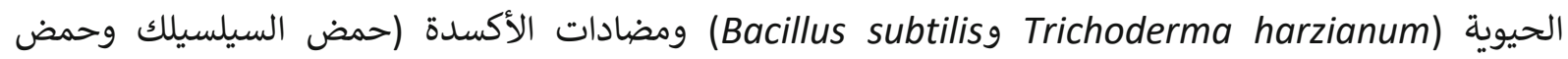

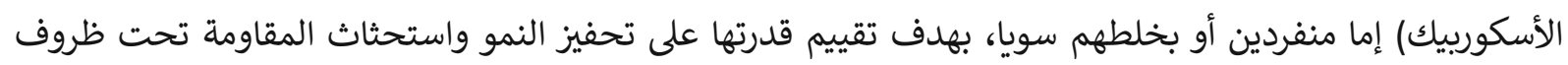

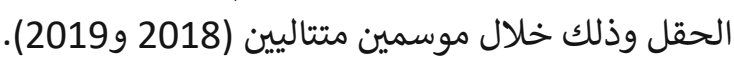

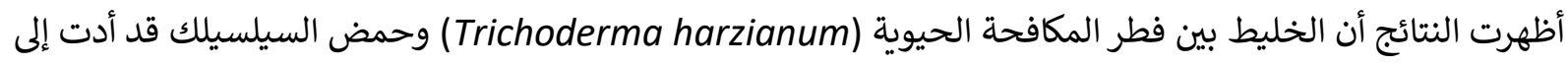

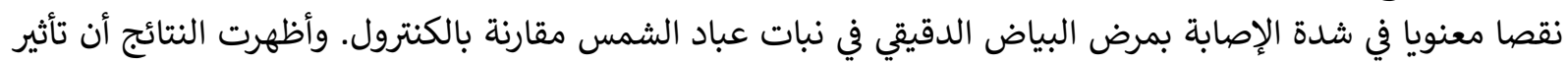

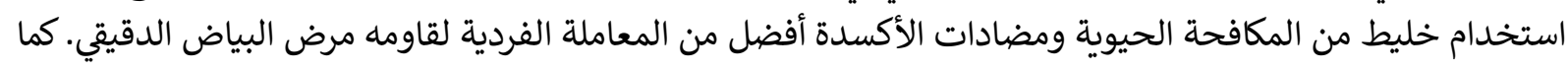

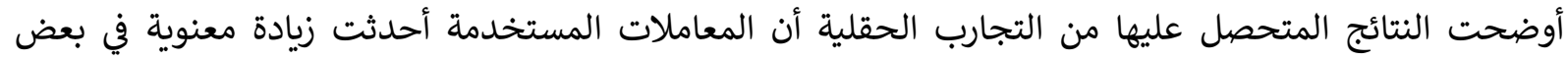

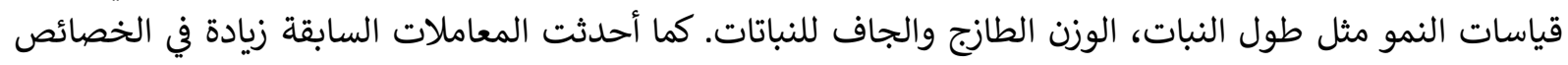

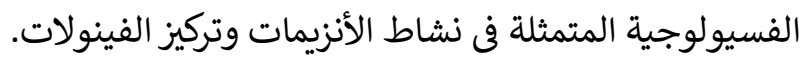

الكلمات المفتاحية: دوار الشمس، البياض الدقيقي، مضادات الأكسدة، العوامل المكافحة الحيوية، المقاومة المستحثة. 